\title{
Contribution of local knowledge towards urban agroforestry as a sustainable approach on climate change adaptation
}

\author{
Jasmin Irisha Jim Ilham ${ }^{1}$, Norizan Esa $^{1 *}$ \\ ${ }^{1}$ School of Educational Studies, Universiti Sains Malaysia, 11800, Pulau Pinang, Malaysia
}

\begin{abstract}
A crucial role in climate change adaptation is the one that should be played by cities. These are major contributors to climate change as well as most vulnerable to the effects of climate change. As urban population in cities increases, so does the greenhouse gas emissions. Urbanisation and the growth of cities continues at great speed, and today the global urban population has increased nine fold since 100 years ago. Though presented with current challenges and threats such as environmental degradation, urban poverty and food security, urban density could create a better quality of life and a lower carbon footprint by innovative approach and more efficient infrastructure planning. Creative solutions are implemented as part of the sustainability component of an integrated, climate resilient city, which comprises of fundamental aspects such as food, water, energy and transport. Application of local knowledge on agroforestry can be utilized in an urban setting, and has positive impacts on a microclimate scale, such as reduces impact of higher rainfall, reduction of greenhouse gas emissions and reduces vulnerability on the urban poor. Urban agroforestry largely contributes to sustainable urban food production opportunities, and encompasses four main fields of practice, including agroecology, urban forestry, urban agriculture and permaculture. This paper examines the local knowledge of agroforestry and how the local knowledge can be transferred into practice in an urban setting, thus providing a sustainable approach towards climate change adaptation in cities.
\end{abstract}

\section{Introduction}

According to the United Nations Populations Division (2014), the population of cities is projected to increase to five billion by 2030, signaling the largest wave of urban growth in recorded history. This situation arises the issue of food and nutritional security as one of the biggest challenges in urban ecosystem. An urban ecosystem can be classified as a group of interacting species that involves humans and their local, non-biotic environment working together as a unit. It can be separated into one single ecosystem or comprised of several individual ecosystem elements such as neighborhoods, watersheds, parks and lakes.

Integration of agroforestry in an urban setting could enhance the sustainability of the area, as well as combat the climate threats that have been evidently occurring at present. Urban agroforestry can reduce the ecological footprint at the certain area by increasing the production of ecosystem services [1]. Agroforestry can be defined as an intensive land-base management practice that integrates trees and woody perennials with agricultural crops and/or livestock. This form of practice optimizes the beneficial interaction of biological, physical and ecological level while ensuring economic needs of the farmer and his community are met [2].

Unique inclusion of trees and woody perennials contributes significantly to the diversity of agroecosystems, which provides soil conservation services, mitigation of pollution at point source, preservation of habitat and sustainability of agronomic products including organic crops [3]. Besides that, agroforestry practices can also include riparian and forest buffers, multi-strata home gardens, windbreaks and temperate zone analog [4].

Complex agroforestry systems depends greatly on processes, be it social or ecological in its management. Based on formal sources, farmer-based system management is being utilized through plating schemes, levels of biodiversity and 
selection of species [5]. However, transfer of agricultural knowledge is also done via social interactions [6] and so its development recognizes the necessity of including local knowledge [7]. In this context, local knowledge, or is also known as indigenous knowledge, means the cumulative and complex forms of knowledge, know-how, representations and practices that are being utilized and developed by peoples who have interacted with the natural environment for a very long time through the ages [8].

\section{Methodology}

Literature searches of electronic journal databases were conducted in order to gather information on contribution of local knowledge towards urban agroforestry as a sustainable approach on climate change adaptation. The key words used were 'local knowledge', 'urban agroforestry', 'cities', 'climate change', 'climate change adaptation'. Publications on research related to local knowledge on urban agroforestry, including review articles and published in English are criteria used for inclusion in the search to improve efficiency

\section{Result and Discussion}

\subsection{Urban Agroforestry}

Agroforestry in an urban setting is still quite uncommon in Malaysia. The integration of woody species such as trees and shrubs together with crops, livestock, or both in a farming system is more familiar in the smallholders sector as opposed to general practice [9]. Since the 1990s, agroforestry was perceived as a form of integrated farming that forms a promising and growing sector in agriculture, but it has yet to become a major undertaking in Malaysia as there are many challenges that accompanies it such as lack of knowledge and budget constraints [10].

There is a rising trend in urban agroforestry practice in home-gardens. Urban gardens in the Pacific Islands present a variety of food trees and non-tree plants that provide supplementary and staple food, including areas like Kiribati and Nauru that is known to have no agricultural diversity [11]. Many of the home gardens surveyed in Papua New Guinea, Fiji, Tonga, Kiribati and Nauru suggested that important staple root crops and supplementary non-tree food plants such as amaranths, onions, peanuts, pineapple, cabbages, as well as a variety of legumes, spinaches, okra, tomatoes, eggplant, corn and condiments such as ginger, coriander and mint were present in large proportion [11].

Home-gardens can also be in multi-strata, which typically consists of multiple species of plants occupying various spatial levels. With this method, energy capture and productivity of the system can be maximized. The multi-strata home-garden is a traditional agroforestry land-use system that include multipurpose trees and shrubs, herbaceous perennials and agronomic crops in polycultures located in close proximity to individual homes [12]. These productive polyculture system is adopted by permaculture and urban agriculture practitioners in cities worldwide as templates for forest gardens or food forests.

Clark and Nicholas (2013) proposed the term Urban Food Forest (UFF) that refers to agricultural practices located in home gardens, community orchards and perennial urban agriculture [13]. As a form of urban agroforestry practice, urban food forestry presents urban edible landscapes that includes food bearing perennial woody species strategically grown in to improve resiliency and sustainability of urban communities via integration of design principles and agroecological as well as plant breeding sciences. This in turn provides an opportunity to increase urban landscape productivity.

A case study by Mohd. Salleh et. al. (2016) from the School of Industrial Technology at Universiti Sains Malaysia shows how plants are grown at rooftop gardens to produce local food for the urban community [14]. Data as of 2016 shows a variety of plants being grown on the roof top garden, which consist of 46 plant species identified. The plant types that are present include herbs ( 21 species), shrubs (12 species), trees (4 species), climbers (4 species), aquatics (3 species), vine (1 species) and fern (1 species). The plant selection is heavily influenced by traditional indigenous gardening knowledge, specifically the Malay community. This is proven by the functionality of plant species, which consist of ornamental, aromatic and shade purposes besides sustainable local food production [15]. 


\subsection{Application of Local Knowledge from Rural to Urban Agroforestry}

The process of urbanization is a threat to practitioners of local knowledge in Malaysia. Preservation of local knowledge is important as it is a comprehensive, dynamic system. Within this system, people are able to continue with their current practices yet at the same time adapt to difficulties encountered in their rapidly changing environment and economic situation that may be challenging to their existence [16].

Most local knowledge that are being practiced focuses on rural agroforestry. This is largely due to resources of man power and persistence to improve economic income in household. The economic status of farmers is also a major factor that contributes to their involvement in agroforestry systems. In Malaysia, an allocation of RM297 million and RM7000 per hectare are distributed to smallholder farmers by the Ministry of Plantation Industries and Commodities (MPIC) and Rubber Industry Smallholders Development Authority (RISDA) [17, 18]. This financial assistance encourages micro level farming system and helps improve the agricultural productivity.

The Sabal Agroforestry Project in Sarawak is an exemplary project that applies local knowledge with participants from six longhouses within the vicinity [19]. The project aims to reduce shifting cultivation inside the permanent forest estate by offering land, materials and incentives to motivate farmers to practice a more sedentary form of agriculture, at the same time increase income and decrease poverty level in rural areas. One of the agroforestry programmes that were implemented at Sabal Forest Reserve is intercropping cash crops with tree crops. This allows local people to plant fruit trees such as durian (Durio zibethinus) in between rows of existing cocoa plants. Other agroforestry programmes that were carried out include planting of fruit trees, coffee and pineapples at existing forest plantation (A. mangium and Shores spp.). The objective is to maximize land use and as a trial basis for compatibility for short-rotation agricultural crops such as coffee and fruit trees. Fish pond and beekeeping were also involved in the programme.

The concept of agroforestry in general is to increase the sustainability of agriculture, regardless of the geographical setting. The main types of local knowledge approach towards agroforestry include home-gardens, shifting cultivation, plantation crop combination and various simultaneous and sequential systems [20]. Out of these approaches, the most common one that is being practiced in an urban setting is home-garden. Young (1989) vouched that this form of agroforestry is highly productive, fully sustainable and very implementable [21]. One of the key advantages for this practice is the labour efficiency due to close proximity to the farmer's residence.

Local influences are evident in settings of home-gardens in Malaysia. The cross disciplinary of practice between agroforestry and ecosystem services such as providing habitat for sunbird, stingless bee and honey bees has made urban farming more unique and attractive. Traditional practices are applied not only on edible plants but also to cater to the co-existence of present biodiversity. This sort of setting can be considered as application of biomimicry technology as the ecosystem replicates several key features of local landscape vegetation that is practiced in traditional house compounds [22]. Greeneries that is formed via home-gardens are visually captivating and is considered as an added aesthetical value for urban landscapes.

The practice of local knowledge in an urban setting is constantly evolving as it needs to be highly adaptable to change. In some circumstances, practices are affected by technological interventions, which greatly enhance the production of crops in an urban as compared to rural setting. Although this improvement contributes towards efficiency, it is more likely that that local solutions in rural areas are less costly and risky as compared to urban areas, where external introductions are involved. Communications is key to ensure that traditional agro-ecological knowledge is being conveyed coherently in order to not only maintain good agroforestry practice, but also as a tool to develop productive participatory relationship with local community, thus engage socio-culturally with one another [23].

\subsection{Urban Agroforestry: Strategy for Climate Change Adaptation}

Climate change is recognized globally as a threat. The World Bank (2010) encouraged new and innovative solutions for adaptations to climate change through environmentally sustainable solutions that involves integrated components of cities as a form of disaster risk management plan [24]. An example identified by The United Nations is urban and per-urban agriculture and forestry (UPAF). A selection of literature review indicates that UPAF has contributed greatly to the urban in enriching their food security, improving the city's natural greenery and urban local climate [25]. 
The concern by local government institutions and municipal councils for sustainable urban and regional planning and development should encourage them to proactively coordinate and implement agriculture and forestry in efforts to enhance food security and increase city resilience. Urban agroforestry contributes positively towards climate change adaptation. For example, by applying agroforestry on steep slopes, it reduces the impacts of high rainfall by minimizing landslides. Implementation and maintenance of urban agroforestry provide much needed shade and improve evapotranspiration, thus reduce the heat island effect. This is a form of passive cooling approach to reduce high temperature in urban areas [26]. Besides that, other particles such as carbon dioxide and dust are captured.

Use of energy in urban areas and emission of greenhouse gases can be reduced via urban agroforestry practice. The local knowledge being implemented in the sustainable process of planting such as composting is a way to reuse organic waste that is productive. This will in turn decrease the amount of organic waste sent to landfills, thus effectively cause less emission of methane gases from landfills. With more compost being produced, the demand for fertilisers will decrease and in doing so, less energy is needed to produce artificial fertilisers. At the same time, the carbon footprint related to the transport of food, storage, cooling and packaging will be reduced with more fresh food available close to home in the city.

\section{Conclusion}

The practice of urban agroforestry in an urban setting is indeed an emerging concept that is still slowly being implemented in Malaysia. However, there is a strong local knowledge influence in agriculture and forestry in urban settings that deserves to be preserved so that the local knowledge can be continuously be applied in future generations to come. It is important that the culture is being shared among the local communities to empower and encourage more people to start their own home-gardens and planting within their home vicinity. It is evident that urban agroforestry is an important player in the adaptation to climate change process. Thus, in order to create better and livable cities, integration of urban agroforestry is definitely the way forward, complemented and driven by the local knowledge for a more sustainable future.

\section{Acknowledgement}

The authors express their gratitude to the Malaysian Ministry of Higher Education for awarding the Long-Term Research Grant (LRGS, 203/PTS/6727002), Universiti Sains Malaysia for the Research University Grant (1001/PGURU/816274) and also all involved in this study.

\section{References}

1. Mann, Urban Agroforestry: Connecting agroecology, permaculture, urban forestry and urban agriculture with agroforestry. Forest 8385, Ecological Principles of Agroforestry, University of Missouri, Columbia (2013)

2. Lassoie, J. P., L. E. Buck, and D. Current, The Development of Agroforestry as an Integrated Land Use Management Strategy Chapter 1 in Garrett, H.E., (ed.). 2009. North American Agroforestry: An Integrated Science and Practice, 2nd edition, American Society of Agronomy, 677 S. Segoe Rd., Madison, WI (2009)

3. Gold, M. A. and H.E. Garrett, Agroforestry Nomenclature, Concepts, and Practices. Chapter 3 in: Garrett, H.E., (ed.). 2009. North American Agroforestry: An Integrated Science and Practice, 2nd edition, American Society of Agronomy, 677 S. Segoe Rd., Madison, WI (2009)

4. USDA Agroforestry Strategic Framework, Fiscal Year 2011-2016 (2011)

5. Beer, J., Muschler, R., Kass, D., Somarriba, E., Shade management in coffee and cacao plantations. Agroforestry Systems 38, 139- 164 (1998)

6. Conley, T. and Udry, C., Social learning through networks: the adoption of new agricultural technologies in Ghana. American Journal of Agricultural Economics, 83, 668-673 (2001)

7. Isaac, M. E., Dawoe, E., Sieciechowicz, K., Assessing Local Knowledge Use in Agroforestry Management with Cognitive Maps. Environmental Management, 34, 1321-1329 (2009)

8. UNESCO, Chapter 13: Enhancing Knowledge and Capacity. In United Nations Educational, Scientific and Cultural Organization (UNESCO), Water a shared responsibility. New York, USA: Berghahn Books \& Paris, France: UNESCO (2006)

9. Jaafar, A. A., Kasiran, N., Muhammed, S., Wan Ismail, W. H., Agroforestry Practices in Malaysia - Integrating Plantation Crops with Timber Species (2014) 
10. Nazip, S. and Suhaimi, M., Agroforestry Practices in Malaysia: Factors that Influence its Implementation. Bureau of Research And Consultancy, Universiti Teknologi MARA, Shah Alam, Selangor, Malaysia (1998)

11. Clarke, W.C. and Thaman, R.R., Agroforestry in the Pacific Islands: System Sustainability. United Nations University Press, Tokyo, Japan (1993)

12. Fernandes, E.C. and Nair, P.R., An evaluation of the structure and function of tropical homegardens. Agricultural systems, 21 (4), 279-310 (1986)

13. Clark, K.H. and Nicholas, K.A., Landscape Ecol 28, 1649 (2013)

14. Mohd. Salleh, A., Azman Lim, N.A., Azam, M.A., Abdul Hamid, M.H., Ibrahim, M.H., Esa, N., Understanding the Adoption of Malay Landscape in a Rooftop Garden Design. USM Press (2016)

15. Rostam, K., Ahmad, R., Hussain, M.Y., Urbanization and the Changing Habitat: The Case of the Malay Housing Compound in Malaysia. Jurnal E-Bangi, 1(1), 1-14 (2006)

16. Richards, P., Indigenous agricultural revolution: ecology and food production in West Africa. Hutchinson, London (1985)

17. Sinar Harian, Risda sedia RM18 juta untuk pekebun getah, sawit (2012)

18. Utusan Borneo, RM297 juta bantu pekebun kecil di bawah NKEA Kelapa Sawit (2011)

19. Kendawang, J.J., The Development and Application of Agroforestry Technology for the Rehabilitation of Tropical Forests in Sarawak, Malaysia. JIRCAS, Working Report No. 60, 9-16 (2009)

20. Long, A.J., and Nair, P.K., Agroforestry system design for the temperate zones: Lessons from the tropics 133139. In: Garrett, H. (Ed) Proceedings for the Second Conference on Agroforestry in North America. University of Missouri, Columbia (1991)

21. Young, Agroforestry for soil conservation ICRAF Science and Practice of Agroforestry series BPCC. Wheatons Ltd, Exeter, UK (1989)

22. Oberndorfer, E., Lundholm, J., Bass, B., Coffman, R. R., Doshi, H., Dunnett, N., Green Roofs as Urban Ecosystems: Ecological Structures, Functions, and Services. BioScience, 57(10), 823-833 (2007)

23. Joshi, L., Arevalo L., Algre J., Sinclair, F., Local Ecological Knowledge in Natural Resource Managment. Paper presented at the conference: Bridging scales and epistemologies, Alexandria, Egypt, 17-20 May 2004, 16 p. (2004)

24. World Bank, Cities and Climate Change: An Urgent Agenda. Washington DC (2010)

25. Dubbeling, M., Urban and peri-urban agriculture and forestry as a strategy for climate adaptation and mitigation. Sustainable Development Knowledge Platform (n.d.)

26. Kamarulzaman, N., Hashim, S. Z., Hashim, H., Saleh, A. A., Green Roof Concepts as Passive Cooling Approach in Tropical Climate - An Overview. E3S Web of Conferences 3, 01028 (2014) 